\title{
FUNCTIONING Soft Power Diplomacy in Foreign Policy: Iran as a Case Study
}

\author{
BASMA KHALEEL NAMUQ M. A \\ Assistant Professor College of Political Science, University of Baghdad research field: political science: \\ international Studies \\ Baghdad Al - JADRIYA Complex, Baghdad, Iraq
}

\begin{abstract}
Objectives: The concept of soft power is considered one of the most important fundamental variables in the field of regional and international relations. Soft power played a major role in implementing the foreign policies of international regional actors, including Iranian foreign policy

The research paper aims to study the impact of employing soft power in implementing Iranian foreign policy by focusing on studying the foundations of Iranian soft power, the role of that power in Iran's foreign policy orientations and the opportunities that support its success

In order to move forward with the policy of Iranian influence in the Arab popular milieu, Iran established many cultural and social centers, in many African and Latin American countries, in addition to establishing many religious and cultural activities, and establishing many civil society organizations in Arab countries such as Iraq. Syria and Lebanon have many satellite channels, newspapers, magazines and radio stations, most of which are funded by Iranian embassies and consulates abroad, and most of them aim to market the Shiite image mixed with Iranian nationalism, and to attract many. Arab and African youth

Methods : The study adopts an analytical, inductive approach that relies on uncovering facts by starting from the details, then proceeds gradually to laws, general rules, and the college, where the parts of the conceptual framework of soft power will be discussed.

At the same time, we explained the challenges that stand in the way of escalating the role of soft power in Iranian foreign policy, and the recent scene in the reliance of Iranian foreign policy in the future on the concept of smart power as a strategy to face the challenges that hinder the achievement of Iranian foreign policy goals regionally and internationally

Results: Our research treatment of the issue of the impact of employing soft powers on Iranian foreign policy as one of the main engines of implementing Iranian foreign policy

An objective analysis was carried out accompanied by a scientific investigation and logical conclusions based on the method of analysis away from repetition and repetition and came out with several conclusions, including the following:

Should Iran's strategy toward the Persian Gulf, the Middle East and North Africa be a strategy of military superiority only, or a bilateral strategy based on employing both soft and hard powers through deep engagement? Conclusions : The debate about the success of the strategy of employing soft power in Iranian foreign policy is based on a logical and objective excuse that it lacks solid experimental ground

Including the dedication of two phenomena:

The first: Promoting the theory of Wilayat al-Faqih through public diplomacy in African and Latin American countries, and this was done through Iran's ambassadors abroad, as well as cultural consulates and political relations with Islamic organizations and movements, as they serve as important power centers in Iranian public diplomacy, and they reinforce the theory of Wilayat al-Faqih

After Iran's 1979 Islamic Revolution, the notion of velayat-e faqih was enshrined into the Iranian constitution, with Khomeini taking on the role of supreme leader until his death in 1989. Today, velayat-e faqih is the sole source of political and religious authority for Iran's supreme leader, now Ayatollah Seyed Ali Khamenei

The second: The religious factor was one of the most prominent obstacles in the way Iran uses its soft power, because (the principle of the jurisprudence of the jurist) was an obstacle to its goal of regional leadership or in generating sufficient soft power to enable it to achieve its regional leadership, or to achieve this goal without relying on hard power.

In fact, this element (the principle of the jurisprudence of the jurist) has often played a negative role in achieving the regional isolation of Iran, especially in the Arab Gulf region.

And when Iran intends to rely on the sectarian factor to mobilize the Shiite minorities in the region and is unable to prove that it does not deal with sectarian politics in many stations, and the tension in the Bahraini-Iranian and Saudi-Iranian relations is the best evidence of the rejection of Iranian proposals based on the principle of exporting the Iranian revolution abroad, especially In the Arab Gulf region

Rather, Iran failed miserably in Iraq and Syria as a result of its reliance on sectarian policies that were rejected by both peoples in these two countries and adhered to the principle of citizenship and loyalty to its homeland instead
\end{abstract}

Keywords : FUNCTIONING . Soft Power Iran . Diplomacy . Foreign Policy . 
DOI: $10.7176 / \mathrm{EJBM} / 13-6-02$ *

Publication date:March $31^{\text {st }} 2021$

\section{Introduction}

The concept of soft power : The term soft power, in its relative novelty, is one of the widely used concepts in the analysis of foreign policies, which is related to the term's contribution to deepening the understanding of the nature of power and its development in international relations

The term soft power revolves around the idea that "strength is the ability to influence the behavior of others", that is, it is a behavioral relationship between two parties, one of which influences the behavior of the other, in a desire to achieve its goals during a specific period of time and through a specific field, and therefore has become soft power A major role in the foreign policies of regional and international actors, and with regard to Iran, it gave fundamental value to soft power because it believes that it possesses the ingredients and sources of that power, which makes it succeed in employing these soft dimensions in its foreign policy in order to achieve the goals it seeks at the regional and international levels

The importance of the research: The importance of the research stems from the following :

First: The American thinker (Joseph Nye) 's vision of the term soft power stems from the idea that there is another non-material aspect of power, the basis and essence of which is the attraction derived from the state's culture, its ideological pattern and its credibility generated by its practices consistent with these values, and based on this idea, this should not be ignored. The other side of the force is the result of focusing on the military and economic dimensions that have won a prominent and pivotal position in the literature of political and international relations and foreign policy

Second: The importance of this study comes by researching the place of soft power in Iranian strategic thinking, on the one hand, and studying an in-depth theory in perceptions and visions that dominated the core of Iranian strategic thinking to employ this force (soft power) in implementing its foreign policy at the regional and international levels

The problem of research: The problem of our research stems from the following objective question :

What is the role of soft power in achieving foreign policy goals at the regional and international levels ?

Research hypothesis: Soft power represented the primary strategic goal of Iran and occupied the most prominent position at the top of strategic thinking for the Iranian political decision-maker in the overall achievement of the goals of their foreign policy regionally and internationally

Research methodology: We have been keen in this study to diversify with many approaches and benefit from them without losing sight of the degree of consistency and consistency required in combining them with an integrated approach that serves this study, we have adopted the descriptive historical approach as well as the analytical and forward-looking approach in an attempt to anticipate the future of soft power and the extent of its success in implementing Iranian foreign policy Regionally and internationally

Research Structure: Our treatment of the subject of our study was distributed by three agencies:

The first topic: introducing the concepts of foreign policy and soft power

The second topic: Iranian employment of the geopolitical dimension of soft power in implementing its foreign policy

Iran's geopolitical site and its challenges in the Middle East and Southwest Asia region

The third topic: a futuristic vision of the role of soft power in Iranian foreign policy: opportunities and restraints introducing the concepts of foreign policy and soft power

\section{The concept of foreign policy}

The foreign policy subject is considered one of the subjects that is characterized by the multiplicity of its study curricula and the intertwining of its subjects, it is one of the basic subjects in the subject of political science.

The study of foreign policy enables us to reveal and understand the national strategies of countries towards their external environments, whether these countries are major or regional and the extent of their influence and the size of their external roles, and also enables us to know the reasons for the weak roles of other countries

And since there is no specific or agreed upon definition of the concept of foreign policy among political scientists in general, and science of international relations or international studies, then the definitions have multiplied each according to the opinion of the researcher or author, (Kurt) provides a definition of foreign policy as the foreign policy of a country from Countries determine their behavior towards other countries, a program whose purpose is to achieve the best possible conditions for the state by peaceful means that do not amount to war ${ }^{1}$

As for Dr. Hamed Rabi', he defines foreign policy all forms of external activity, even if they are not issued by the

\footnotetext{
${ }^{1}$ Joseph S. Nye (Jr.), Soft Power: The Means to Success in World Politics (New York: Public Affairs, 2004): 1-8; Joseph S. Nye (4))Jr.), "Public Diplomacy and Soft Power", The Annals of the American Academy of Political and Social Science 616, Public Diplomacy in a Changing World (March 2008): 107 .
} 
state as a systemic fact, the group's activity as a civilized presence or self-expressions as individual images of the external movement involves and falls under this broad section that is called foreign policy ${ }^{1}$

There is another definition, which is (the art of running a foreign country in gathering fields with the rest of the international actors, whether they are international people, countries, international organizations or other international pressure groups, and this art is governed by the national interest) $)^{2}$

Charles Hermann "knew foreign policy by saying," foreign policy consists of those distinctive official behaviors of official government decision-makers or their representatives that are intended to influence the behavior of the foreign state ${ }^{3}$.

Also, "Mazen Ramadan" defines foreign policy as "targeted and influential external political behavior for decisionmakers"4

"Modelsky" defined foreign policy in the same direction as Hamed Rabie, who said: Foreign policy is: "The system of activities that societies develop to change the behavior of other countries and to establish according to the international environment.

In this framework there are two types of activities: inputs and outputs." 5

Marcel Merle defines it as "that part of government activity directed abroad, that is, which deals with the opposite of domestic politics, problems that arise beyond borders" ${ }^{6}$.

The foreign policy is not always an activity. Countries that pursue a policy of neutrality or stagnation and closure on the external environment do not carry out an activity towards that environment, and this confirms that the foreign policy is not always an expression of the activity carried out by the state because the external activities of states do not aim in their entirety to change The behavior of other countries, it may aim to preserve the status quo. Also, the foreign policy of countries is not only directed to states but also to all actors of the international system The concept of using scientific logic in foreign policy revolves around three main concepts:

The ability to predict the reaction, followed by a model of movement

Visualizing the results of the political movement and its effects at the internal, regional and international levels.

Measuring public opinion to discover the real trends in preparing a specific decision

Public opinion here should be understood as internal and regional public opinion ${ }^{7}$

The state follows a certain orientation in its foreign policy, printing it for a period of time that may be longer or shorter, according to the suitability of its national interests

The regional trend may deviate from directing the foreign policy of the state according to its geographical field. There are countries that direct its foreign policy towards its regional field and do not give any attention to issues that are far from its territory ${ }^{8}$

The regional trend corresponds to the global trend, whereby the state in this case directs its foreign policy towards international units outside its territory

Sometimes the decision maker seeks to pursue a foreign policy orientation that seeks to establish the current pattern of international relations, and between a foreign policy orientation that seeks to change the current pattern of international relations into an ideal and perceived pattern. The orientation of recognition or change in the current international relations does not only deviate from regional issues, but includes all international issues around the globe.

The policies that seek to change the status quo in international relations are the politics of international alliances and blocs

The interventionist approach stems from the international unit seeking to influence the policies of other international units and direct them to influence the composition of the existing political authority.

This approach is often adopted by the major powers and the regional states, which always search for influence and seek to preserve their national interests outside their region. ${ }^{9}$

\section{The Concept of Soft Power :}

The concept of power is one of the basic concepts in political science. Researchers and those interested in

\footnotetext{
${ }^{1}$ Hamed Rabi’, (1973) Foreign Policy Theory, Modern Cairo Library, Cairo, , p. 101 .

2 Joseph S. Nye (Jr.), "Soft Power”, Foreign Policy, no. 80 (Autumn 1990): 153-171; Joseph S. Nye (Jr.), Bound to Lead: The (2) Changing Nature of American Power (New York: Basic Books, 1991): 188-220 .

${ }^{3}$ Hill, Norman K, (1962) International Politics, New York Happer and Row, , P. 33 .4

${ }^{4}$ Ellen Hallams, "From Crusader to Exemplar: Bush, Obama and the Reinvigoration of America's Soft Power", European Journal of American Studies 6, no. 1 (Spring 2011): 9-16, online e-article, http://journals.openedition.org/ejas/pdf/9157

${ }^{5}$ Palmer Jillin, Clifton Morgan, ( 2011) Theory of Foreign Policy. Translation: Abdul Salam Ali Al-Nuwair Riyadh: Scientific Publication and Press _ King Saud University,

${ }^{6}$.Johnson Lloyd, (1989) Interpretation of Foreign Policy. Translation: Muhammad bin Ahmad Mufti, Muhammad al-Sayyid Salim). Riyadh: Deanship of Library Affairs, King Saud University ,

${ }^{7}$ Mr. Salim Muhammad, (1988) Foreign Policy Analysis. Source previously mentioned p. 1018

${ }^{8}$ Ahmad Al-Naimi, (2009) Foreign Policy. Amman: Zahran Publishing and Distribution House, , p. 23

9 Gabrielle Angey-Sentuc and Jérémie Molho, "A Critical Approach to Soft Power: Grasping Contemporary Turkey's Influence in the World", European Journal of Turkish Studies, no. 21 (2015): 13-14, online e-article, http://ejts.revues.org/5287
} 
international relations do not disagree that power is the primary ruler of relations between countries.

Power can be defined as the ability to influence the behavior of others to obtain desired results or the ability to impose control on others

However, the essence of the concept, as mentioned by Carl Friedrich Gauss, is to establish a dependency relationship between two parties

through which the first party can cause the second party to do whatever it wants, that is, to act in a way that adds to the interests of the power owner

Soft power means that the state has a spiritual and moral force through its embodiment of ideas, principles and ethics and through support in the areas of human rights, infrastructure, culture and art, which leads others to respect and admire this method and then follow its sources

Soft power is a concept coined by Harvard University's Joseph Nye to describe the ability to attract and unite without coercion or using force as a means of persuasion

Soft power is the power of the model, the attractiveness of culture, the transcendence of values and principles, and the credibility in committing to all of this. It is the possession of characteristics that make others look to the state as a role model and a source of inspiration

Soft power is the ability to influence others so that what you want becomes the same what they want, and that your values, culture, principles and your way of life become the model they want to follow. The spread of fast food with its famous brands from the United States to the rest of the world gives America soft power

Soft power arises from a country's "cultural attractiveness, the political ideals it holds, and the policies it pursues in reality, and when American policies appear legitimate in the eyes of others, American soft power expands. When we make others admire the ideals we believe in, and make them want what we want, we will not have to Spending a lot on traditional policy resources - the stick and the carrot - that is, on factors of military compulsion and economic temptation. One of the most important American ideals that have the power to move and attract others toward democracy, human rights and opportunities for individuals

And when soft power is defined by behavior it becomes simply "the attractive force conducive to desired and desired behavior."

And Joseph Nye looks at "soft power depending on what is going on in the mind and mind of the recipient".

And it is not possible for any strategic communication campaign, no matter how large or expanded, to affect the public sphere of others, and it promotes slogans, demands, issues, values, and policies that are not popularly desirable.

Joseph Nye identified soft power resources in three tracks

American culture and ideals in places that are attractive to others.

Political values when they are faithfully applied at home and abroad.

Foreign policies when viewed by others as legitimate and of moral and moral authority. ${ }^{2}$

Whereas the sources producing soft power resources are: ${ }^{3}$

Hollywood factories, armies of American artists and actors, and film production

The armies of foreign students and researchers to study in universities and educational institutions, they will form armies carrying thousands of them

Good intentions and good deposits when they return to their countries and homelands and assume higher positions and locations and they will become unofficial ambassadors to serve America.

Immigrants and foreign businessmen in the American business sector.

The Internet, the global search engines Google, Yahoo, Twitter, Facebook and others, and American sites scattered in the electronic space.

International cultural and scientific exchange programs and international conferences.

Intercontinental economic companies, especially the communications and information sector.

As for Robert Gates, the former US Defense Secretary, defined soft power according to his military background, describing it as "the ability to define and direct behavior rather than imposing will

Meanwhile, Michael Eisenstadt, a researcher specializing in military and security studies at the Washington Institute for Near East Studies, defined it as "the use of emotional words, actions and images in the context of a long-term strategic campaign for communication to shape the psychological state of an anti-American country like Iran".

And he specified that the percentage of media statements and statements should constitute $20 \%$ of the soft strategic communication campaign, while the remaining $80 \%$ of programs, actions and concrete actions on the ground will

\footnotetext{
${ }^{1}$ Gabrielle Angey-Sentuc and Jérémie Molho, “A Critical Approach to Soft Power. Grasping Contemporary Turkey’s Influence in the World”, European Journal of Turkish Studies, no. 21 (2015): 13-14, online e-article, http://journals.openedition.org/ejits/5287

${ }^{2}$ Muhammad Hamdan(2013) Soft Power and Remote Conflict Management, Hammurabi Center for Research and Strategic Studies, first edition, , p. 23

${ }^{3}$ Janice Bially Mattern, “Why 'Soft Power' Isn't So Soft: Representational Force and the Sociolinguistic Construction of )Attraction in World Politics", in Power in World Politics, edited by Felix Berenskoetter and Michael J. Williams (London:
} 
be formed".

More recently, the term has been used to influence and change social and public opinion through relatively less transparent channels and pressure through political and non-political organizations. ${ }^{1}$

The real attempt after World War II was to use soft power through the Fulbright Program for student exchange around the world in 1946 as a way to influence cultures and dominate the minds of other societies. Soft power was used extensively during the ideological struggle between the socialist and capitalist camps and the tendency of each Who are in influencing other's minds and tendencies

After the fall of the Soviet Union, the theory of soft power emerged at the hands of Joseph Nye and was used by America a lot after the fall of the Soviet Union to emphasize the unipolar system and spread the values of freedom, democracy, human rights and the disposal of fascist regimes to the US war on Iraq in 2003 that brought back the concept of soft power to use A lot in international relations,

With soft power, Joseph Nye said, "the best advertisements are not propaganda," explaining that in the information age, "credibility is the rarest resource".

This term was coined by Joseph Nye in his 1990 book entitled "Capable of Leadership: The Changing Nature of American Power". He developed the concept in his 2004 book entitled

Soft Power: The Means of Success in International Politics. The term is now widely used in international affairs by analysts and politicians. ${ }^{2}$

In the presence of senior leaders of the US military, led by former defense minister Leon Panetta, chief of the Joint Chiefs of Staff and various weapons commanders, and on the platform of a press conference he held at Defense Department headquarters, US President Obama unveiled the most important features of the strategic review, or what It was termed "the new US defense strategy and the enhancement of the United States' leadership in the world defense priorities for the 21 st century :"

Sustaining U.S. Global Leadership: Priorities for

Century Defense

The document consists of 128 pages. It took a full year to draft, and 700 personalities from the Ministry of Defense, armament systems, relevant study centers, and military experts in this regard participated in preparing it.

What is really interesting is that this strategy was issued nearly a year and a half after the rise of this administration (the Obama administration).

This means that the Obama administration, for nearly a year and a half, remained without a national security strategy, which prompted many observers to adopt a view that assumed that the Obama administration adopted the strategies of the Bush era.

For example, General Secretary of the Communist Party of China Hu Jintao spoke in 2007 that China needs to increase its soft power.

US Defense Secretary Robert Gates spoke of the need to strengthen American soft power by "increasing spending on civilian tools from national security through diplomacy, strategic communications, foreign assistance, reconstruction and economic development." 3

The foundations of Iranian soft power

First: The Iranian Wilayat al-Faqih

The concept of velayat-e faqih (in Farsi, or wilayat al-faqih in Arabic) transfers all political and religious authority to the Shia clergy and makes all of the state's key decisions subject to approval by a supreme clerical leader, the vali-e faqih (guardian Islamic jurist). The supreme clerical leader (the faqih) provides guardianship (velayat) over the nation and, in doing so, ensures the top-down Islamisation of the state

Velayat-e faqih - or guardianship of the Islamic jurist - is system of governance that has underpinned the way Iran operates since the country's 1979 Islamic Revolution. At its most basic, the theory of velayat-e faqih, which is rooted in Shia Islam, justifies the rule of the clergy over the state. Velayat-e faqih is at the crux of Shia Islamism and is fundamental in understanding not only how the Iranian system operates but also how Tehran can influence religious and political Shia networks beyond its borders .

Second: Persian culture and civilization

Third: the doctrinal pattern of the principles and objectives of the Iranian foreign policy

\footnotetext{
${ }^{1}$ Michael P. Marks, Metaphors in International Relations Theory (New York: Palgrave Macmillan, 2011): 97-101. (Rose McDermott, Political Psychology in International Relations, Analytical Perspectives on Politics Ann Arbor: The Michigan University Press, 2004): 169-187.,

${ }^{2}$ Niall Ferguson, “Think Again: Power", Foreign Policy, no. 134 (2003): 18-22.

${ }^{3}$ Joseph S. Nye, Soft Power: The Means To Success In World Politics, Op. Cit., P: 11 .16 Joshua Kurlantzick, Charm Offensive: How China's Soft Power Is Transforming the World (New Haven, CT: Yale University Press, 2007): 6; Peter Brookes, "Iran: Our Military Options", The Heritage Foundation, www.heritage.org/homeland-security/commentary/iran-our-military-options. Christopher A. Ford, "Soft on 'Soft Power"”, The SAIS Review of International Affairs 32, no. 1 (Winter-Spring 2012):89 )
} 


\section{Iranian employment of the geopolitical dimension of soft power in implementing its foreign policy Iran's geopolitical site and its challenges in the Middle East and Southwest Asia region}

Pierre Renovan) says in an introduction to the history of international relations about the importance of the geopolitical site of the state:

The study of the geopolitical position of a country is not intended to be the abstract definition that links the land of political unity with certain features, or is related to astronomical or descriptive determinations, but rather geopolitics aims to highlight the actual value of the geographical location because it gives the state a special personality and directs its policy In certain directions, it affects its strength, how its vital interests are, and the role it can play in its regional and international arenas ... etc.

Iran is located between the latitude (25) and (40) north of the equator and between longitudes (44) and (63) east of the Greenwich Line, and as such, it is located most of its territory within the warm temperate tropical region. This means that Iran is extended to the latitude of (15). This extension had a great impact on the diversity of climatic regions and the diversity of natural plants.

It is bordered by Turkmenistan and Azerbaijan to the north, Turkey and Iraq to the west, Afghanistan and Pakistan to the east, and the Persian Gulf to the south, where Iran overlooks a sea front of approximately $1660 \mathrm{~km}$, and it has another sea front in the north on the Caspian Sea, which is $800 \mathrm{~km}$ long, and the total area The state is 1648 thousand square kilometers, which is equivalent to approximately 634 thousand miles.

Iran has an excellent geographical location, making it a land bridge between the countries of the eastern Mediterranean on the one hand and the countries of central and southern Asia on the other for several centuries, when the main trade routes crossed the northern part of the country, and Iran's average location between the sphere of influence of two great countries (the United Kingdom and the Soviet Union) During the past decades, it was a special strategic importance, which made it an area of intense competition between them, as well as it was one of the main crossings that were used by the Allied Forces to extend supplies to the former Soviet Union during its resistance to the German invasion during World War II $^{1}$ (17)

Iran can be divided into four major geographical regions with geographical phenomena and features in the republic :

Western Highlands.

Eastern Highlands.

Northern Highlands.

Central Plateau Territory.

Iranian coasts bordering the Gulf of Oman and the Persian Gulf have an unusual strategic geo value In giving Iran a distinct geopolitical weight, because it is at the forefront of the factors that help the state in building its naval power, especially

If we know that the two Gulfs of Oman and the Arabian Gulf have importance in linking the world of the Atlantic Ocean to the Indian Ocean in the unique theory, what is the role of the naval power in controlling the world, and indeed Iran has benefited from these two Gulfs in building its naval bases so that it becomes a force to be reckoned with in the balance Strategic in the region

Among the most important of these rules are (Bandar Abbas, Bushehr, Kharj Island, Bandar Khomeini, Abadan, Jahhabhar

The last is the main three-role base that contains facilities for the land, sea and air forces), and by this, Iran has been able to interfere and influence oil supplies, commercial movement and war movement in the Persian Gulf ${ }^{2}$ Accordingly, Russia is still Russia, with the value of Iran's unusual geopolitical position on the Persian Gulf and the Caspian Sea due to the US approach to the Gulf and the Caspian Sea region, which has geo-economic importance to completely remove Russian influence from this region according to the comprehensive plan that begins with NATO's expansion towards the western frontiers of Russia in depth (The Asian side) of Russia in a region that has been for centuries within the circle of vital interests of Russia. As a result, Russia is seeking to consolidate its relations with Iran as the only savior to get rid of American pressure, especially since the cooperation of Iran and Russia will weaken the importance of Find US support for Turkey and Azerbaijan in the region $^{3}$

And the study (Clifford German) in 1960 was a serious attempt in the field of controlling the force measurement of the state through the following equation:

State power is equal to nuclear capabilities (area, population, size of industrial base, size of military force It is not possible to measure the variables of the Iranian force, rough or soft, in isolation from the historical legacy of the strategic directions of the state or towards the vital field of the state. The geopolitical variable represents one of the most important determinants of the vital field of the state, and accordingly, the political regions surrounding Iran can be divided.

Which defines its geostrategic tendency to four regions of my agency

\footnotetext{
${ }^{1}$ The political system in Iran http://clp.uhd.edu.iq

2 .bakhash, Shaul, (1984) Reign of the Ayatollahs: Iran and the Islamic Revolution by Shaul, Bakhash, Basic Books, p. 158-9

${ }^{3}$.Joseph S. Nye, Soft Power: The Means To Success In World Politics, Op. Cit., P: 1119 . 19
} 
Fertile Crescent Region (Iraq, Syria, Lebanon, Palestine, Jordan

Caucasus region (Azerbaijan, Georgia, Armenia and parts of Anatolia

The Central Asian region from the eastern Caspian Sea to the northern Chinese border, plus Afghanistan

Southern Region (South Pakistan and Southeast Arabia

And the future of Iran depends on its eastern neighborhood more than its dependence on the western neighborhood, and one of these indicators in the contemporary period is Iran's presence as an observer in the Shanghai Cooperation Organization, while the Arab Gulf states did not accept Iran's joining it in any regulatory framework

Therefore, Iran has sought, since the founding of its (Islamic) revolution, through the ambition to build itself as a major regional

power spreading its influence in its surroundings, which it considered a strategic environment to achieve its interests

The process of building this force includes two main parts, namely

Solid force (military), which is working to develop it despite all the difficulties that stand before it in this

The soft power through which it seeks to find incubating evidence that accepts and supports its expansionist offer in the Arab world. Among the most prominent elements of Iranian soft power are the following ${ }^{2}:(21)$

First: diplomacy

Since the year $1979 \mathrm{AD}$, and the establishment of Wilayat al-Faqih state as an ideological revolution, new diplomacy has begun to be used effectively for soft power tools, and for the concept of the Islamic revolution to be exported under various names, it must first reach the minds of the target people.

Considering that Iranian diplomacy is a behavioral activity linked to an objective and associated with an influential ability taken by Iran to confront other units of the international system

Iranian writer (Bizen Yazdi) defines Iranian diplomacy as it is a work and an art of employment for all legitimate and permissible capabilities to secure the interests of the Islamic nation ... in the field of international relations Where Iranian diplomacy is a tool and a means to achieve the goals of Iranian foreign policy regionally and internationally

In this regard, Ali Akbar Salehi, a former Iranian foreign minister, says

Soft diplomacy is today one of the axes and main elements of the Iranian diplomatic apparatus, because if the speech is soft, it can remove even the strong evidence and proof, so the human being is Abdel-Ahsan, which is something that can be seen in our foreign policy ${ }^{3}$

Perhaps the results of the Geneva negotiations $(5+1)$ are evidence of the ingenuity of Iranian diplomacy and the potential of the Iranian

diplomatic apparatus and its ability to employ soft power and its tools .

Therefore, Iranian diplomats are more open to the peoples of the region, specifically in the societal and cultural activities that are the mainstay of Iranian soft power, as Iranian diplomats use all available tools to create a positive image of Iran in the capitals in which Iranian embassies are located, there are cultural representatives and responsible for public diplomacy This is evidence that Iran's decision-maker is planning this diplomacy accurately and systematically. In the early eighties of the last century, and after the end of the civil war in Lebanon, the Iranian presence in the southern suburbs of Beirut and in the south of Lebanon was the first to export the revolution in cultivating a military wing affiliated to it, represented by the Lebanese Hezbollah, and later Iran established many armed Shiite factions in Iraq, Syria and Yemen Afghanistan, Pakistan, Bahrain and Saudi Arabia

First: The Religious Factor (Shiite Awakening as Iran's Soft Power

The contemporary Iranian Republic arose from a mixture of religious theocracy and Western democratic tools, to preserve the authority of religious thought and its men as the founding thought of the state as a whole.

Shiite Islam emerged as the most powerful force during the (Islamic Revolution) in 1979, when its power reached that it not only led the revolutionary struggle against the Shah of Iran, but ultimately formed the ideological superstructure of the new Iran after the revolution.

And the role of Islam was not limited to shaping the fabric of contemporary Iran, but rather it transcended it to form its relations with the outside world, and through the slogan (exporting revolutionary Islam) or what is known as (Wilayat al-Faqih)(Writer (Hassan Ahmad Al-Omari) says in his article entitled

The political decision in Iran between the revolution and the state) is based on the idea of revolutionary Islam, and understanding this radical Islam that Iranian leaders believe in is an essential condition for understanding the strategies and policies of the Iranian regime internally and externally. It has adopted the Iranian constitution (theory

\footnotetext{
${ }^{1}$ Arjomand, Said Amir (1988), The Turban for the Crown: The Islamic Revolution in Iran, Oxford University Press, , p. 144

${ }^{2}$ Ezdi, Bezen, ( 2000) An Introduction to Iranian Foreign Policy, Translated by Saad Sabbagh, 1st Floor, Cultural Publishing House, Cairo, , p 201

${ }^{3}$ Ali Hussein Bakir,( April 17, 2013 ) Discovering Iranian Soft Power, Capabilities and Limits of Influence, Al-Jazirah Center for Studies, Wednesday, ,http://studies.aljazeera.net/ar/files/iranandstrengthfactors/2013/04/2013411102151266414.html\%20\%5BAccessed\%206\%20Jan $\% 202014 \% 5 \mathrm{D}$
} 
of the absolute jurisprudence ${ }^{1}$

And the fifth article of the Iranian constitution states (In the time of the absence of Imam Mahdi, peace be upon him), the guardianship of the matter and the nation in front of the Islamic Republic of Iran will be in the hands of a fair and pious jurist with insight into matters of the brave era capable of administration and management.....

Article (177) of the Iranian constitution stipulates that it is not possible to change the guardianship of the jurist or the contents of the articles related to the regime of Islam or the goals of the Islamic Republic of Iran. Therefore, Iran seeks to make its interpretation of Islam the first among the Shiite communities around the world by spending huge money to support activities Iranian clerics trained in Qom and imbued with the jurisprudence ideology Iran seeks to create solidarity ties with Shiite communities around the world that could serve as external support bases for its policies and as allies in the event that Iran is attacked by Israel or the United States of America. Second: Iranian culture (Persian language)

The Iranian researcher (Abbas Al-Maliki) believes that the Iranian soft power sources are represented by many elements, the most prominent of which are:

Farsi culture or language, considering that the Farsi language is an essential element in attracting other nations, as it has entered into the synthesis of many other languages prevalent today in the world, such as Turkish, Hindi, Urdu, Armenian, Georgian, Swahili, etc. and that there are not a large number of languages around the world that are free of the Persian language and traditions Iranian and Shi'ism

Political values include democracy, elections, women's rights, and civil society

Foreign policies include legitimacy, prestige and public relations

In the year 2005, the Iranian regime tried to exploit all sources of soft power and its tools that Iran enjoyed within one strategy that includes a clear policy for employing soft power in the context of the great

Iranian national strategy to be more effective in serving Iranian national interests and foreign policy of $\operatorname{Iran}^{2}(24)$ Third: Cultural Promotion

Iran spends a lot of money on the level of cultural promotion to serve its national project. In 2008, Iran's cultural budget reached about 5500 billion tomans, of which 386 billion tomans went to the Ministry of Culture and Islamic Guidance, and the rest was spent on Iranian propaganda and cultural activities. Iran has used other means, including the following:

The revolutionary discourse hostile to America and Israel and the purpose is to win large sectors of public opinion in its favor, especially at the regional level

The Palestinian cause, and through a speech aiming to support the Palestinian cause, also aims to gain public opinion in its favor and to attract the Arab street to create an appropriate environment to accept the Iranian regional role through this section ${ }^{3}$

\section{A Futuristic Vision of The Role of Soft Power in Iranian Foreign Policy: Opportunities and Restraints}

The Iranian revolution in 1979 was the event that had the greatest impact on Iranian foreign policy because of the change taking place inside Iran and in its vision of the outside world and to change the map of allies and opponents in the regional and international environment.

From this historical moment, the Iranian decision-maker has suffered from confusion and confusion between the dictates of the national interest and the requirements of ideological goals that changed the sources of threats to the Iranian state and the opportunities presented to the Iranian regime

In the post-guide of Iran (Mr. Khomeini) and after the Iraq-Iran war, the stage of Iran's guide (Mr. Khamenei), Iranian foreign policy has worked to help achieve economic goals in an attempt to develop trade and foreign investment that Iran desperately needs to rebuild what was destroyed by the war.

Rafsanjani's main slogan was constructive, and opening up to the outside became an important goal for attracting foreign investment, stopping the deterioration of the economic situation and preserving the system itself The importance of the economic dimension continued in the shadow of Mr. Khatami and the current Hassan Rouhani stage, the current Iranian president, so the focus was on technology transfer and trade development, but under a broader concept of development that contains not only the political but also cultural dimensions that the Khatami administration used efficiently in order to maintain the bridges of the outstretched dialogue with countries that falter Developing the relationship with it in the way that Iran aspires to "Iranian foreign policy is no longer based on rejection or support of anything, but rather on the basis of a deliberate stance and its own analysis of the international community.".

\footnotetext{
${ }^{1}$ Ali Jalal Moawad, (2019) The Concept of Soft Power and Foreign Policy Analysis, Egypt: Bibliotheca Alexandrina, Center for Strategic Studies .,

2 Firas Elias, ( 05/10/2019). “The Main Pillars of Iranian People's Diplomacy,” The New Iraq Center, website: https://www.newiraqcenter.com , Speech, Sadiq Zibya, (2013) Shiite Awakening as a Soft Power, News Analysis, Al-Jazirah Center for Studies, , studies.aljazeera.net

${ }^{3}$ Mohammadi, Manouchehr, (2010) The Islamic Revolution in Iran Compared to the French and Russian Revolutions, Arabization: Haider Najaf, 1st Floor, Dar Al-Maaref Al-Hikmiah, Lebanon .
} 
In other words, there has been a shift in the objectives of Iranian foreign policy from merely trying to confront local emergency conditions and meeting needs in light of the existing status quo to trying to know international conditions, so that Iranian foreign policy is no longer based on rejection or support of something but rather based on a considered position and its own analysis of the international community It is a new trend that differs from what prevailed during the era of Rafsanjani and seeks to present an Iranian vision of the international system and Iran's role in it. Thus, it can be said that Iran's foreign policy has gone from being a chain reaction to the real formulation stage that has its future plans ${ }^{1}$.

In this context, Iran proposed the concept of a dialogue of civilizations, which succeeded in returning foreign policy to its correct cultural path, contrary to what was prevalent in the past only on the economic side. The decision-maker's orientation towards the outside world has become based on a cultural strategy that stems from an attempt to promote Iranian culture and civilization for more success in the policy of opening up to the world, which Iran has no alternative at this historic moment in the international system - and indeed this call for dialogue between Civilizations

The following question may be asked :

Has soft power played an important role in Iranian foreign policy, especially through the cultural medium and its flexible diplomacy?

Iranian researcher (Mohammad Reza Bajouh) indicates that Iran does not use the country's capabilities in soft power correctly, which had been employed in foreign and diplomatic policy would have had a deeper and greater impact on the regional and international system

In the context of his assessment of the extent of the Iranian government's success in implementing the twenty-year strategy (2025), which is supposed to generate enormous soft power for Iran, the Iranian researcher (Jahangar Amazjar) studied the results of the fourth fiftieth plan that ended in 2010 to assess the path of the Iranian government towards 2025 and the result was as He said (back from bad to worse) ${ }^{2}$ (27)

For several reasons, the most prominent of which are the following ${ }^{3}:$ (28)

First: The Iranian soft power had reached its climax in the Arab world by 2006 and remained steadfast until 2008 as it began to decline rapidly until it deteriorated with the outbreak of the Arab revolutions at the end of 2010 and the beginning of 2011 and then deepened with the outbreak of the Syrian revolution and its continuation and continued to decline after the emergence of popular protests in Iraq is the end of 2019, as Iran lost its popular weight and political and economic influence in Iraq as a result of the emergence of a new Iraqi youth generation who rejected Iranian hegemony in all its forms and held Iran responsible for the deteriorating conditions of the Iraqi people economically because of Iran's support for the corrupt ruling parties in Iraq

Second, the fact remains that Iran follows the Shiite doctrine and mixes it with Persian nationalism, specifically The principle of ( wilayat al-faqih) is a factor obstructing its goal of leading the region or generating enough soft power to enable it to achieve this goal without relying on a solid force

In fact, this element has often played a negative role in achieving Iran's regional isolation, especially when Iran intends to rely on the sectarian factor to mobilize Shiite minorities in the region and is unable to demonstrate that it does not deal with sectarian policies in many stations and tension in the Bahraini-Iranian and Saudi-Iranian relations is good a proof of that

Rather, Iran failed a great failure in Iraq and Syria as a result of its reliance on sectarian policies that both peoples in these two countries rejected and adhered to the principle of citizenship and loyalty to its homeland instead of it. This leads to an automatic reaction by rejecting Iranian proposals based on the principle of exporting the Iranian revolution abroad, especially in the Arab Gulf region.

Third: The limited influence of the cultural factor (Persian)

The cultural factor (the Persian language) remains limited in spite of its possession (Iran) of soft power resources and tools to influence the civilizational norm, but this region also was and still depends or is subject to competition from major players greater than Iran from the former Soviet Union to Russia, China and the United States today Not to mention that most of the population of these countries neighboring Iran are affiliated with Turkey nationally or annually, and it is a sectarian factor in itself for Iran's efforts, especially with the Turkish rise

Fourth: In the field of foreign policies, it can be said that Iran's tools for using its soft power in this field are very loose and unstable, and depend on the mistakes of others and the vacuum they leave, and as soon as they return or the equation is corrected until Iran loses the ability and negates or weakens the soft power in this field.

\footnotetext{
1 .Isa, Muhammad Ziauddin, (2017) "Current Iranian Politics Toward the Nile Basin Countries," Afaq Afriqiyah Magazine, Article 13, 46 .,

${ }^{2}$ Al-Awamleh, Khalid, (1992) The Iranian Revolution and the Legitimacy of Arab Political Systems, Unpublished Doctoral dissertation, Cairo University, Faculty of Economics and Political Science, , p. 518 .Al-Batniji, Ayyad,( 05/10/2019). "Iranian Foreign Policy: A Comparative Critical Study," Center for Strategic Studies, website: http://cssrd.org.lb ,

3 28.Ali Hussain Bakir, Discovering Iranian Poft http://studies.aljazeera.net/ar/files/iranandstrengthfactors/2013/04/2013411102151266414.html\%20\%5BAccessed\%206\%20Jan.\%202014\%5 $\underline{\mathrm{D}}$
} 


\section{Conclusion}

Depending on the (Principle of Wilayat al-Faqih), Iran was able to complete the export of its Islamic project to many countries in Asia, Africa, and Latin America, and the goal is to achieve the following matters :

First: culturally attracting young people

In order to go further in the Iranian influence policy in the Arab popular milieu, Iran has established many cultural and social centers, in many African countries and Latin America, in addition to establishing many religious and cultural activities, and establishing many civil society organizations in Arab countries such as Iraq, Syria Lebanon, opening many satellite channels, newspapers, magazines and radio stations, most of which are funded by Iranian embassies and consulates abroad, most of which aim to market the Shiite image mixed with Iranian nationalism, and attract many Arab and African youth

Second: Employing scholarships and studies in Iranian universities to promote cultural expansion

To this end, Iran has also gone towards opening several study programs to attract young people in Africa and Latin America to study in Iran

Third: Using Hajj for political purposes,

Iran has launched many programs to facilitate the opportunities of Hajj and Umrah, by opening many offices in this regard in Arab African and Islamic countries. It provides most of the simple families unable to perform Hajj with free cards for the Hajj, and besides this it provides them with many books and brochures that guide Biography of the Iranian Shiite image, in order to create elements of influence in the Arab and Islamic psyche to accept the Iranian jurist mandate for application in their countries.

Fourth: Iranian diplomacy

Iran's ambassadors abroad, along with cultural consulates, and political relations with Islamic organizations and movements, act as important power centers in Iranian public diplomacy, and promote the theory of Wilayat alFaqih, so in order to understand the soft power that Iran creates through public diplomacy in African and Latin American countries, we need An increase in the number of Iranian cultural representation in those countries for the purpose of increasing their cultural activities.

Despite this, Iran failed to employ its soft power in many African countries, America, and even the Arab countries. The religious factor was one of the most prominent constraints in the way of employing Iran its soft power because (the principle of jurisprudence of the jurist) was a hindrance to its goal in leading the region or generating enough soft power that would enable it to achieve an investigation This goal without relying on solid strength

In fact, this element has often played a negative role in achieving Iran's regional isolation, especially when Iran intends to rely on the sectarian factor to mobilize Shiite minorities in the region and is unable to demonstrate that it does not deal with sectarian policies in many stations and tension in the Bahraini-Iranian and Saudi-Iranian relations is good a proof of that

Rather, Iran failed a great failure in Iraq and Syria as a result of its reliance on sectarian policies that both peoples in these two countries rejected and adhered to the principle of citizenship and loyalty to its homeland instead of it. This leads to an automatic reaction by rejecting Iranian proposals based on the principle of exporting the Iranian revolution abroad, especially in the Arab Gulf region

The foundations of Iranian soft power, and its effect on the failure of Iran's experiment in employing soft power in its regional foreign policy, especially towards the Arab Gulf and North Africa.

As a result of the peculiarity of the ruling theocratic regime in Tehran, it reflected negatively on the failure of Iran's experiment in employing soft power in its foreign policy .

First: The justification that won the ruling political system in Tehran a soft power represented in an ideological ideology based on the Islamic religion and the Shiite doctrine, with which he had influence and influence among most Muslims forty years ago, due to the ideological power that was able to attract and attract a large majority of Muslims through spiritual and ideological propositions It is evident from it the influence of the ideological factor on Iranian foreign policy through successive historical periods to govern the conservative and reformist religious currents of political power in Iran

Second: The impact of the Iranian mandate of al-Faqih on the internal and external Iranian political decisionmaking

The Iranian political system constitutes a peculiarity in its strategy and decision-making, so it is one of the most prominent foundations on which the soft power was built, especially in the aspect of the organizational structure of its institutions or the theory of guardianship of the jurist, which gave the Supreme Leader - the Wali al-Faqih absolute powers on the ground, where these powers overwhelm the Constitution And formal and informal institutions, this aspect of the influence of the political system in creating soft power has become pivotal and central in managing the political, economic and social files in the country and abroad. It is justified that the authority of the political system in this framework is compatible with the nature of the revolution and its requirements

Third: The impact of the Persian cultural heritage on the identity of the Iranian society with a Shiite Islamic character 
While the Iranian identity is a fundamental pillar of the foundations on which soft power in Iran was built The society of Persia, where this Persian culture meets in the form of populist, mass and elitist values and practices, is the fruit of activity related to the Iranian Shiite environment, whose ability to communicate with others is activated by a large stock of culture, the natural product of ethnic, national and religious pluralism in Iran, which generates soft power and influence in society The Shiite spread in the Arab Gulf states, Iraq, Lebanon, Yemen, North Africa, and especially Egypt

Which helped to raise the balance of soft power and define its political behavior, for an objective consideration that clarifies that they are societal variables closely related to the reactions of the ruling religious political system in Tehran towards various internal and external issues. The soft power of Iran has been linked to the main source of attracting others and practicing persuading them with Shiite Islamic ideas

To be published and exported, according to the Iranian mandate

Fourth: Persian cultural and civilization homogeneity with the Islamic civilization of a Shiite nature helped to supplement Iran's soft power and gave the Iranian political decision maker great confidence and ability to employ the Islamic religion of Shiite doctrine and all the components, factors and sources of soft power in the realization of its expansion projects and its foreign policy and the transmission of the values of the Iranian revolution (Wilayat al-Faqih) and export to the outside world

Fourth: The impact of the Iranian Islamic identity with a Shiite character on Iranian foreign policy

In particular, building its political structure within the Iranian constitution

As the head of the regime and its civil and military institutions was based on (the Iranian constitution) from a religious doctrine that raised a slogan, neither East nor Western, seeks not to follow any international axis and to distance itself from the major powers and their political blocs at the regional level

This is reflected in the Iranian Shiite Islamic identity with religious specificity, as it achieves the goals that the ruling political system in Iran seeks to achieve through soft power at the lowest costs, unlike hard power

Fifth: The Iranian soft power experiment failed due to the problem of duplication between Iran's rhetoric based on spreading the Iranian revolution and the attempt by Iran to employ soft power

Because of the problem of Iran's foreign policy understanding of the emerging contradictions between its ideological political rhetoric based on velayat-e faqih and its soft practices, while Iran harnesses all its soft powers to convince the world of the success of its political model, it is simultaneously practicing solid foreign policies that seek to obliterate borders and abolish state sovereignty through Its influential interference in the affairs of other countries, including the Arab Gulf states and North Africa

This is one of Iran's most prominent failures to employ soft power in its foreign policy regionally and internationally

Experts and researchers confirm the Iranian issue

The Iranian foreign policy is directed towards the Gulf states and North Africa

It has gone through three basic stages,

The first phase: the period of the coming of Sayed Khomeini, the supreme guide of the Islamic Republic of Iran, after 1979

The second phase since the Iraqi invasion of Kuwait on the second of August 1990, and the third and final phase, it is associated with the start of the so-called Arab Spring. Especially since the arrival of the political Islam movement in a number of Arab countries encouraged Iran to take advantage of that situation and increase its influence and regional influence, especially in Bahrain (Bahraini Hezbollah), Yemen (the Shiite Houthi experience), Lebanon (Lebanese Hezbollah) and Iraq (Iraqi Shiite factions) Pro-Iran) and Syria (support for the Syrian Ba'ath Party regime) etc.

Sixth: The impact of the problematic of the "Shiite" Islamic nationalism theory, the theory of exporting the Iranian Khomeinist revolution, and considering it the most important function of the Iranian Islamic state, in order to establish a just world government, on the failure of Iran's experiment in employing soft power in its foreign policy Iran, through Wilayat al-Faqih, tried to re-divide the Middle East and North Africa region according to colonial ideological foundations that serve the interests of the powers that dominate this region, and the main target in it is the Arab world by eliminating any role it has in these strategies, and eliminating its political, economic and cultural effectiveness, the most important of which are: The theory of Islamic "Shiite nationalism", the theory of exporting the Iranian Khomeinist revolution, and considering it the most important functions of the Iranian Islamic state, to establish a just world government, the theory of the Wali al-Faqih, which is based on the concept that Iran is the center of global "Islam", and finally the theory of the "Islamic Middle East", Which imposes Iranian hegemony over the entire Middle East, with the Arab world at its heart, and imposes a global Islamic government led by Iran, which intersects with the theories of the new, large and expanded Middle East, both American and Israeli

Experts and researchers confirm the following real Arab Gulf states

By adopting the decision to withdraw its military forces from Iraq at the end of 2011, the administration of US President Barack Obama will bear the exacerbation and increase of Iranian influence in the Arab Gulf region and North Africa because it led to the reinforcement of sectarianism, the spread of terrorism, and the expansion of 
terrorist groups

Especially (ISIS) and the formation and support of armed sectarian militias, which poses a threat to societal cohesion in the Arabian Gulf and North Africa.

This was achieved through direct Iranian interference in the affairs of Iraq, Syria, Lebanon, Yemen, Bahrain and Saudi Arabia

Although the administration of US President Donald Trump succeeded through the use of the strategy of severe economic strangulation and the imposition of economic sanctions on Iran, from a decline in the Iranian role in the region

Seventh: Since smart power is the ability to combine hard power with soft power of attraction in a successful strategy or policy that achieves the country's objectives at the foreign policy level

However, Iran has failed to adopt the smart power strategy as an approach or mediator between hard and soft power

The reason is the Iranian guardianship of the jurist, which is based on spreading the Iranian Shiite revolution abroad

This has made Iran today in a state of regional isolation, especially from the Gulf states and North Africa 